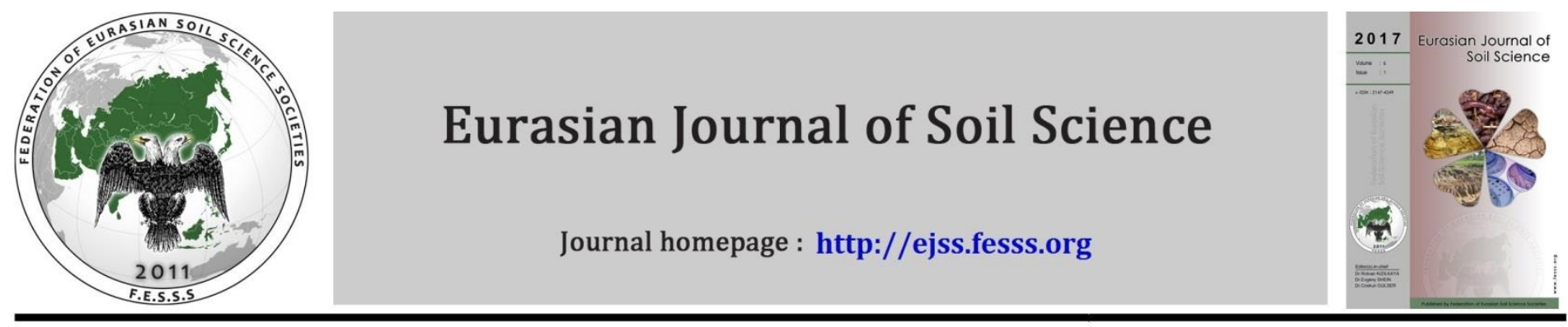

\title{
Tropical chemical weathering of a garnet rich micaschist in the rainforest zone of Cameroon
}

\author{
Désiré Tsozué a,*, Rose Yongue-Fouateu ${ }^{\mathrm{b}}$ \\ a Department of Earth Science, Faculty of Science, University of Maroua, Maroua, Cameroon \\ b Department of Earth Science, Faculty of Science, University of Yaoundé I, Yaoundé, Cameroon
}

\section{Article Info}

Received : 22.03.2016

Accepted : 17.05.2016

\begin{abstract}
Soils developed on garnet-rich micaschist in the Southern Cameroon plateau were investigated. Morphologically, two weathering materials constituted the study profile, fine earth and nodules. Each material has a singular evolution from the coarse saprolite to the upper set of clayey and loose horizons. There is $\mathrm{Al}_{2} \mathrm{O}_{3}$ enrichment in the fine earth concomitantly to $\mathrm{Fe}_{2} \mathrm{O}_{3}, \mathrm{Na}_{2} \mathrm{O}$ and $\mathrm{K}_{2} \mathrm{O}$ enrichment in nodules in major element$\mathrm{Al}_{2} \mathrm{O}_{3}$ variation diagrams. $\mathrm{A}-\mathrm{CN}-\mathrm{K}$ and $\mathrm{A}-\mathrm{CNK}-\mathrm{FM}$ diagrams show a progressive depletion of $\mathrm{Al}$ in nodules concomitantly to an enrichment of this element in the fine earth. Three pedogenetic processes emerge from the evolution of weathering products. There is a ferruginization process whose importance increases from the coarse saprolite to the upper set of clayey and loose horizons, giving rise to the formation of dense nodules composed of hematite, goethite and gibbsite. This ferruginization occurs concomitantly with a desaluminization process, which causes $\mathrm{Al}_{2} \mathrm{O}_{3}$ depletion in nodules. These nodules are formed by the process of induration where the hydrated amorphous hydroxide and oxides are dehydrated to their crystalline oxide form, due to condensation. In addition, there is aluminization, which occurs in the fine earth, leading to the development of a red clayey material composed of kaolinite and gibbsite.
\end{abstract}

Keywords: Laterite, ferruginization, desaluminization, aluminization, Cameroon.

(C) 2017 Federation of Eurasian Soil Science Societies. All rights reserved

\section{Introduction}

Enormous volumes of rocks are involved in the biogeochemical weathering that affects continental surfaces. Among this, about tens of meters of thickness over about one third of all emerged lands are today undergoing lateritization (Nahon, 2003). Lateritization processes homogenize the weathering products through intense leaching of alkaline, alkaline-earth elements and some silica of the parent rock, and lead to a mineralogical reorganization of silica, alumina and iron oxides (Davy and El Ansary, 1986; Nahon, 1991; Tardy, 1993). These processes lead to the formation of laterites, which are the main constituents of weathering mantles in the tropical zone (McFarlane, 1976). They are complex materials derived from the weathering of various rock types (Tardy, 1993; Thomas, 1994; Beauvais, 2009; Ndjigui et al., 2008; 2013; Tsozué et al., 2011; 2012; Wouatong et al., 2013). Their profiles result from intense chemical weathering in intertropical zones and have commonly developed over several millions of years (Tardy, 1993; Tardy and Roquin, 1998). A remarkable amount of literature exits on the mechanism of chemical weathering under different geomorphic and paleoclimatic conditions (Wouatong et al., 2005; Deepthy and Balakrishnan, 2005; Nguetnkam et al., 2008; Kamgang et al., 2009). Weathering is the alteration and breakdown of rock and soil

\footnotetext{
${ }^{*}$ Corresponding author.

Department of Earth Science, Faculty of Science, University of Maroua, P0 Box 814 Maroua, Cameroon

Tel.: +237675121489

E-mail address: tsozudsir@yahoo.fr 
materials at and near the earth's surface by physical, chemical and biological processes. Some of the mineral elements may be released, forming secondary minerals, particularly clay minerals. Chemical weathering in tropical regions favours extensive lateritization which is the cementation of sesquioxide-rich soil horizons (Helgren and Butzer, 1977; Aristizábal et al., 2005) and formation of deeply weathered profiles (Irfan, 1996; Voicu and Bardoux, 2002). The main chemical factors that usually control the weathering of rocks include solution $\mathrm{pH}$, parent material composition and crystallinity, microenvironment, oxidation-reduction potentials, temperature and ionic strength (Wouatong et al., 2013).

Chemical weathering indices based on quantitative measurements based on whole-rock chemical analyses are commonly used to characterize the intensity and mechanisms of weathering (Nesbitt and Young, 1982; Irfan, 1996, 1999; Ng et al., 2001; Gupta and Rao, 2001; Voicu and Bardoux, 2002; Aristizábal et al., 2005; Wouatong et al., 2013). Recent works have shown that weathering indices based on the ratio of a group of mobile elements to one or more immobile elements are useful parameters for characterizing changes induced by weathering (Duzgoren-Aydin et al., 2002; Aristizábal et al., 2005; Wouatong et al., 2013). The elements more mobile during weathering are generally used to quantify the effects of chemical weathering on heterogeneous weathering residua (Price and Velbel, 2003; Aristizábal et al., 2005; Wouatong et al., 2013). Nesbitt and Young $(1982,1984,1989)$ and Nesbitt et al. (1996) used ternary A-CN-K and A-CNK-FM diagrams to deduce weathering trends. These authors demonstrated that the bulk compositions of diverse rocks composition follow simple trends that are largely unaffected by the climatic conditions under which weathering took place (Aristizábal et al., 2005; Wouatong et al., 2013). In addition to providing a method of visualizing the degree of weathering, the $\mathrm{A}-\mathrm{CN}-\mathrm{K}$ system permits the evaluation of the weathering trends from fresh rock compositions through their weathering products (Fedo et al., 1995; Aristizábal et al., 2005; Wouatong et al., 2013).

The intensity of chemical weathering is determined by factors like climate, parent material, topography and vegetation. It is generally accepted that chemical weathering is more developed in tropical areas. This is even more important in areas with dense vegetation and a smooth topography, leading thus to the decomposition and/or transformation of original minerals in the bedrocks. Recent characterization of soils developed on garnet rich micaschist in the rainforest zone of Cameroon have shown that nodules observed in the nodular horizon have been formed in situ, directly from the original garnet grains in the bedrock (Tsozué et al., 2011). They are fundamentally different from degradation and aggradation nodules commonly described in the tropical zone (Tardy, 1993). The garnet rich micaschist might undergo differential weathering where garnet minerals exhibit a completely different evolution from that of the other minerals which constitute the bedrock.

The main objective of this study is to investigate weathering trends and intensity, chemical behavior of major elements, improve the understanding of the different weathering processes occurring during the decomposition and/or the transformation of the garnet rich micaschist into a thick weathering mantle under the tropical rainforest of the Southern Cameroon in Central Africa.

\section{Material and Methods}

\section{Study site}

The study site is located in the Southern Cameroon plateau, approximately between longitudes $13^{\circ} 23^{\prime} 30^{\prime \prime} \mathrm{E}$ to $13^{\circ} 24^{\prime} 30^{\prime \prime} \mathrm{E}$ and latitudes $3^{\circ} 43^{\prime} 33^{\prime \prime} \mathrm{N}$ to $3^{\circ} 44^{\prime} 45^{\prime \prime N}$ (Figure 1). The Southern Cameroon plateau belongs to the African 1 Surface, with altitude between 600 and $800 \mathrm{~m}$ a.s.l., which is observed in addition to Cameroon, in Central Africa Republic (CAR), Equatorial Guinea (EG), Gabon and Congo (Figure 1). The study site emerges from the whole Southern Cameroon plateau by its altitude of about $840 \mathrm{~m}$ a.sl. The climate is an equatorial type with two dry seasons alternating with two wet ones and a mean annual rainfall of $1640 \mathrm{~mm}$, a mean annual temperature of $23^{\circ} \mathrm{C}$ and an average annual relative humidity of $80 \%$ (Suchel, 1987), favourable for the development of a dense evergreen forest which is strongly degraded by human activities around the villages (Letouzey, 1985). Such climatic conditions are suitable for supergene weathering leading to the formation of red ferrallitic soils (Yongué-Fouateu et al., 2006). The slopes are gentle (6-10\%), separated from each other by narrow and outstretched valleys. The bedrock is a massive garnet-rich micaschist. In addition to garnet mineral, there are muscovite, biotite, feldspar and quartz. Microchemical analyses reveal that garnets are grossularite-rich almandine type. 


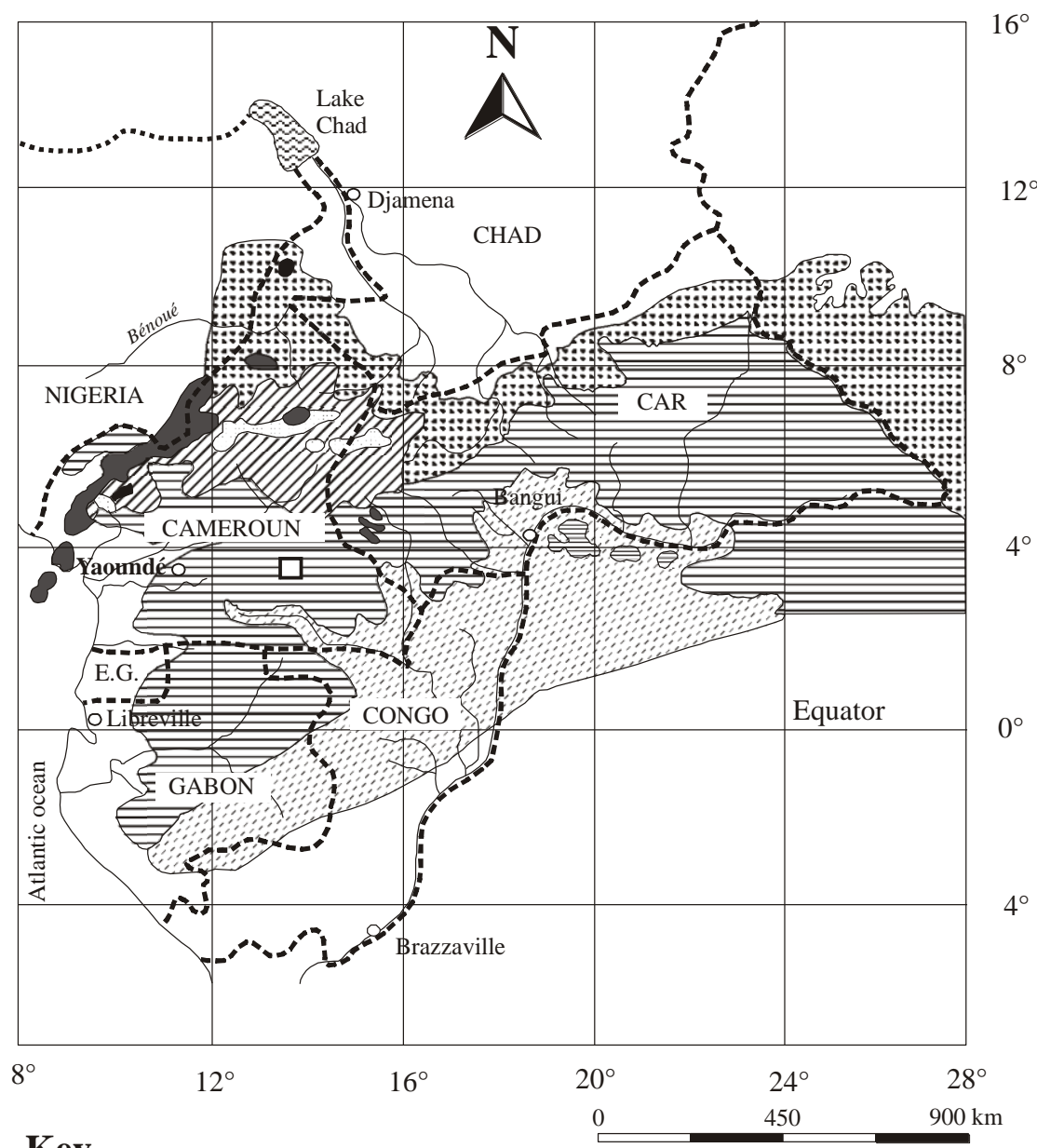

$\underline{\text { Key }}$

Mountains

Gondwanian Surface

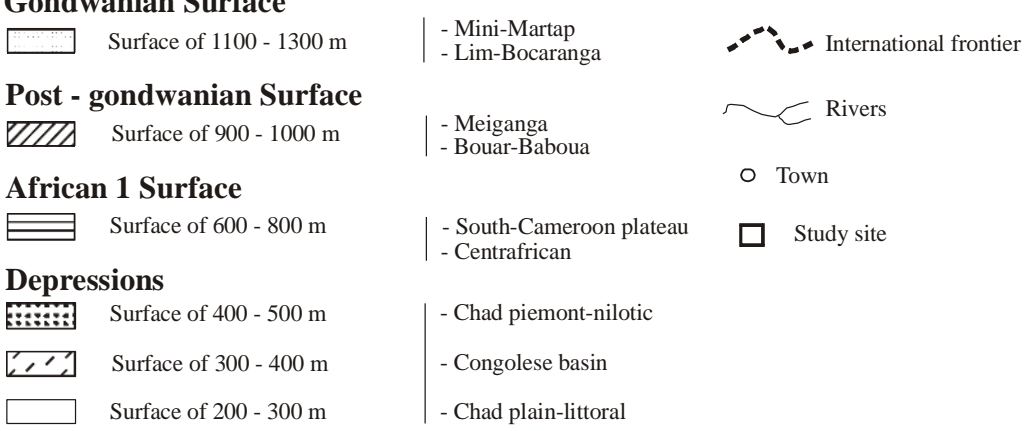

Figure 1. Location of the study area (modified after Temgoua (2001)).

\section{Experimental design}

An unweathered garnet-rich micaschiste sample was collected on outcrops in the valley near the studied interfluves, together with soil samples in the studied profile.

In the laboratory, three main types of analyses were conducted. They are microscopic, mineralogical and geochemical analyses. Microscopic analyses consisted of observations of fifteen soil and two rock thin sections under the polarizing microscope. Soil thin sections were obtained after impregnation with resin and then hardening in the air. Soil thin sections were described using the terminology proposed by Stoops (2003). Mineralogical analyses were done by X-ray diffraction (XRD) on total sample powders, using a Philips PW2400 XRD spectrometer with copper anode and equipped with a xenon detector, whose characteristics are: wavelength $\lambda=1,54 \times 10^{-10} \mathrm{~m}$, energy $\mathrm{E}=40 \mathrm{kV}$. For samples containing goethite, percentage substitution rates in moles of AlOOH were calculated by Thiel (1963) method, based on Vegard's law and reflecting the proportionality between the distance lattice and the substitution rate. Loss on ignition 
(LOI) was determined by ignition of samples at $1050^{\circ} \mathrm{C}$ for two hours. Geochemical analyses were made by X-ray fluorescence on total samples powder. They were performed using a Philips PW 1404 WD XRF spectrometer. The detection limit was $0.01 \%$.

The behaviour of chemical elements, throughout the profile was approached by calculating elements mass balance during weathering. These mass balances were done following the calculated 'mass balance method' (Brimhall and Dietrich, 1987; Brimhall et al., 1988; Colin et al., 1992) by considering titanium as an immobile element (Anderson et al., 2002). It is based on the residual enrichment in closed systems and supergene enrichment in open systems, which previously need the determination of horizon deformation rates. This method enables to estimate the quantity of each element which is depleted or accumulated (Colin et al., 1993). Horizon deformation rate $(\varepsilon)$, element mobilization rate $(\boldsymbol{\tau})$ and total mass of mobilized elements $(\mathrm{m})$ in each horizon were calculated according to the following equations:

$$
\varepsilon_{a}=\frac{C_{i, p} \cdot d_{p}}{C_{i, a} \cdot d_{a}}-1 \quad ; \tau_{j, a}=\frac{d_{a}}{d_{p}} \frac{C_{j, a}}{C_{j, p}}\left(\varepsilon_{a}+1\right)-1 \quad ; \quad m_{j, p}=\left(\frac{C_{j, p}}{100} \cdot d p \cdot v p\right) \tau_{j, p}
$$

In these, $\mathrm{Ci}, \mathrm{p}$ and $\mathrm{Ci}$, a are the concentrations of an invariant element $\mathrm{i}$ (in this case, $\mathrm{Ti}$ ) respectively in the parent rock p and the horizon a; $\mathrm{Cj}, \mathrm{p}$ and $\mathrm{Cj}$, a are concentrations of any common element $\mathrm{j}$, respectively, in the parent rock $\mathrm{p}$ and the horizon $\mathrm{a}$; $\mathrm{dp}$ and da are, respectively, the bulk density of the parent rock $\mathrm{p}$ and the horizon a; vp is the parent rock volume which corresponds to $1 \mathrm{~cm}^{3}$ (Brimhall et al., 1985).

\section{Results}

\section{Morphological, mineralogical and geochemical characterization of the studied profile}

The studied profile is about $10 \mathrm{~m}$ thick and made up of four horizons, from bottom to top (Figure 2, Table 1): - a coarse saprolite (10 to $8.25 \mathrm{~m}$ ), which is gray yellow with a well preserved bedrock structure and the presence of numerous pink globular garnet crystals. Mineralogically, the horizon is dominated by muscovite, goethite, quartz, gibbsite and kaolinite, with an addition of hematite and traces of anatase in the "ghost"of unweathered garnets (Table 2). The loose material is mainly composed of $\mathrm{SiO}_{2}(62.60 \%)$, with a small amount of $\mathrm{Al}, \mathrm{Fe}, \mathrm{K}, \mathrm{Na}, \mathrm{Ca}$ and $\mathrm{Mg}$ (Table 3). In the "ghost" of garnet, Si contents are low meanwhile $\mathrm{Al}$ and Mg contents are high (Table 3);

- a fine saprolite (8.25 to $6.20 \mathrm{~m}$ ), red, with many isalteritic relicts, ferruginized friable quartz blocks and nodules, embedded in a clayey matrix with a very weakly developed blocky structure. Microscopically, it is characterized by a weakly birefringent micromass with a locally undifferentiated b-fabric, but sometimes with a stipple speckled b-fabric. Coarse materials represent about $30 \%$ of the red loose clay matrix, with double spaced porphyric c/f related distribution patterns. This assemblage is constituted by muscovite, quartz, kaolinite, gibbsite, goethite, hematite and traces of anatase (Table 2). $\mathrm{SiO}_{2}$ contents decrease, $\mathrm{Al}_{2} \mathrm{O}_{3}$ contents increase in the matrix and $\mathrm{Fe}_{2} \mathrm{O}_{3}$ contents increase slightly in nodules, whereas other oxide contents are almost constant (Table 3 );

- a nodular horizon ( 6.20 to $4.60 \mathrm{~m}$ ), composed of about $40 \%$ of nodules embedded in a red clayey matrix with fine blocky structure. Nodules show a groundmass consisting of an orange-brown birefringent micromass (goethitic) or a darker and undifferentiated micromass (hematitic). The mineral composition is muscovite, kaolinite gibbsite, goethite, hematite, quartz and traces of anatase, with high expression of gibbsite in nodules (Table 2). $\mathrm{Si}, \mathrm{Al}$ and $\mathrm{Fe}$ are the most abundant elements both in the matrix $\left(57.38 \% \mathrm{SiO}_{2}\right.$, $\left.15.03 \mathrm{Al}_{2} \mathrm{O}_{3}, 5.62 \% \mathrm{Fe}_{2} \mathrm{O}_{3}\right)$ and in the nodules $\left(47.23 \% \mathrm{SiO}_{2}, 15.83 \% \mathrm{Al}_{2} \mathrm{O}_{3}, 8.12 \% \mathrm{Fe}_{2} \mathrm{O}_{3}\right.$ ) (Table 1). $\mathrm{K}_{2} \mathrm{O}, \mathrm{MgO}$, $\mathrm{Na}_{2} \mathrm{O}$ and $\mathrm{CaO}$ contents remain almost constant but well represented here as in the other horizons (Table 3);

- a set of red clayey and loose horizons (4.60 to $0 \mathrm{~m}$ ), subdivided from bottom to top into a dense deep horizon (4.60 to 3.30), an aliatic horizon (3.30 to 1.50), a compact horizon (1.50 to $0.08 \mathrm{~m}$ ), identical to the matrix described in the nodular horizon, and a very thin surficial humiferous horizon (0.08 to $0 \mathrm{~m})$. The groundmass has a moderately to highly separated microstructure. It contains a few quantities of nodules, less than or equal to $3 \mathrm{~mm}$ in diameter. Coarse material represents 10 to $20 \%$ of the groundmass, with double spaced porphyric to open porphyric c/f related distribution patterns. The mineral assemblage is composed of kaolinite, quartz, gibbsite, hematite and traces of muscovite (Table 2). Si, $\mathrm{Al}$ and Fe are the most abundant elements $\left(52.04 \% \mathrm{SiO}_{2}, 20.12 \% \mathrm{Al}_{2} \mathrm{O}_{3}, 6.23 \% \mathrm{Fe}_{2} \mathrm{O}_{3}\right)$ (Table 3). They are followed by $\mathrm{K}(4.02 \%$ $\left.\mathrm{K}_{2} \mathrm{O}\right), \mathrm{Na}\left(1.32 \% \mathrm{Na}_{2} \mathrm{O}\right)$, $\mathrm{Ca}(1.92 \% \mathrm{CaO})$ and $\mathrm{Mg}(2.70 \% \mathrm{MgO})$ which remain present here as in the other horizons (Table 3). 


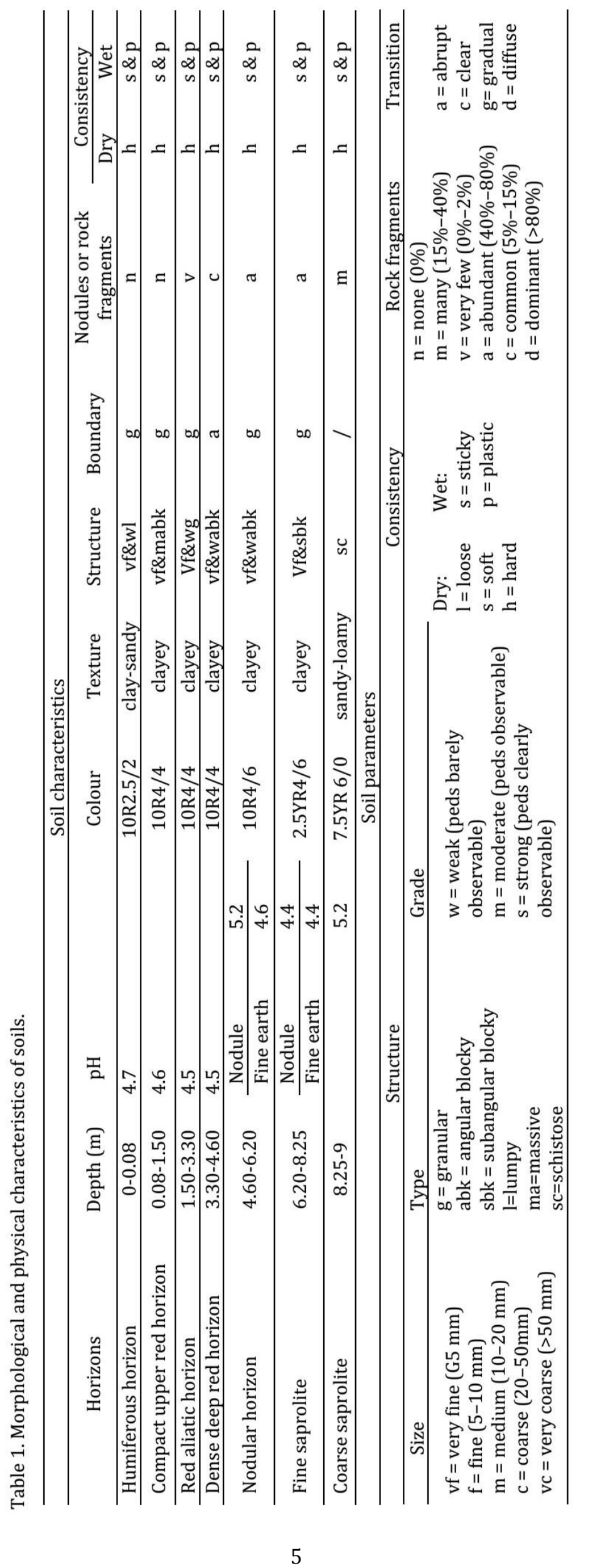




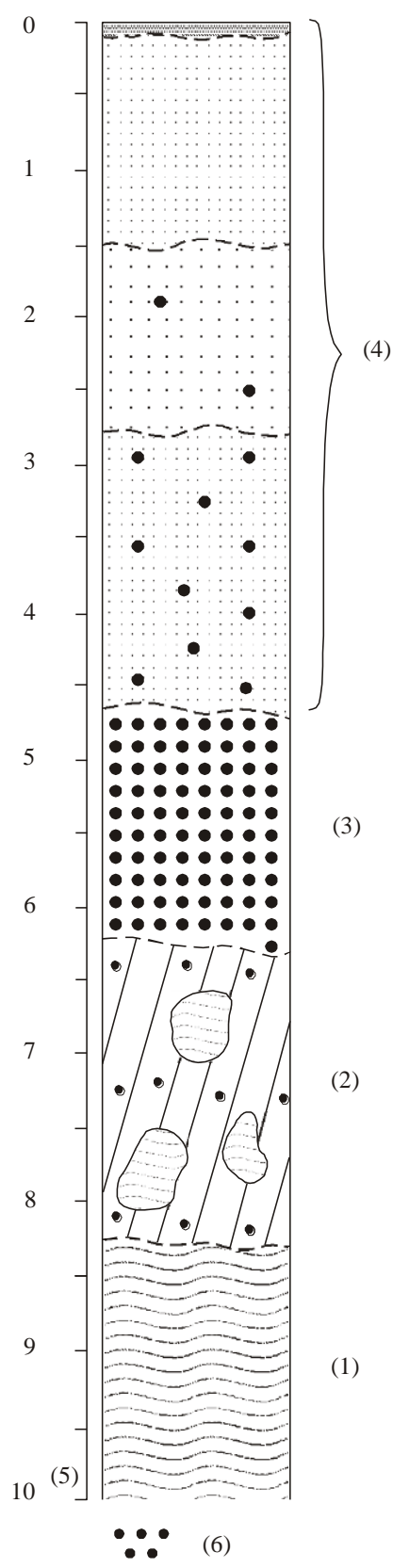

Figure 2. Macroscopic organization of the studied weathering profile: 1. coarse saprolite; 2. fine saprolite; 3. nodular horizon; 4. set of clayey and loose horizons; 5. depth (m); 6. nodules.

Table 2. Mineralogical composition of soils

\begin{tabular}{|c|c|c|c|c|c|c|c|c|c|}
\hline Horizons & Depth (m) & M & $\mathrm{K}$ & $\mathrm{Gi}$ & Goe & $\mathrm{He}$ & Q & A & $\begin{array}{c}\text { \% moles of } \\
\text { AlOOH } \\
\text { in goethite }\end{array}$ \\
\hline $\begin{array}{l}\text { Set of clayey and loose } \\
\text { horizons }\end{array}$ & $(1.25 \mathrm{~m})$ & + & +++ & ++ & / & + & ++++ & / & / \\
\hline \multirow{2}{*}{ Nodular horizon } & Nodules $(5.5 \mathrm{~m})$ & + & / & ++++ & ++ & ++ & +++ & / & 9 \\
\hline & Fine earth $(5.5 \mathrm{~m})$ & ++ & ++ & ++ & I & + & ++++ & + & I \\
\hline \multirow{2}{*}{ Fine saprolite } & Nodules $(8 \mathrm{~m})$ & + & + & +++ & ++ & + & +++ & + & 8 \\
\hline & Fine earth $(8 \mathrm{~m})$ & ++ & ++ & ++ & / & + & ++++ & + & / \\
\hline \multirow{2}{*}{ Coarse saprolite } & "ghost" of garnet (9 m) & ++ & + & +++ & ++ & + & ++ & + & 9 \\
\hline & Fine earth $(9 \mathrm{~m})$ & +++ & + & ++ & +++ & / & +++ & / & 10 \\
\hline
\end{tabular}

/: non identified ; + : traces ; ++: very deficient ; +++: deficient ; ++++: abundant

M: muscovite ; K: kaolinite ; Gi: gibbsite ; Goe: goethite ; Q: quartz ; He: hematite ; A: anatase 


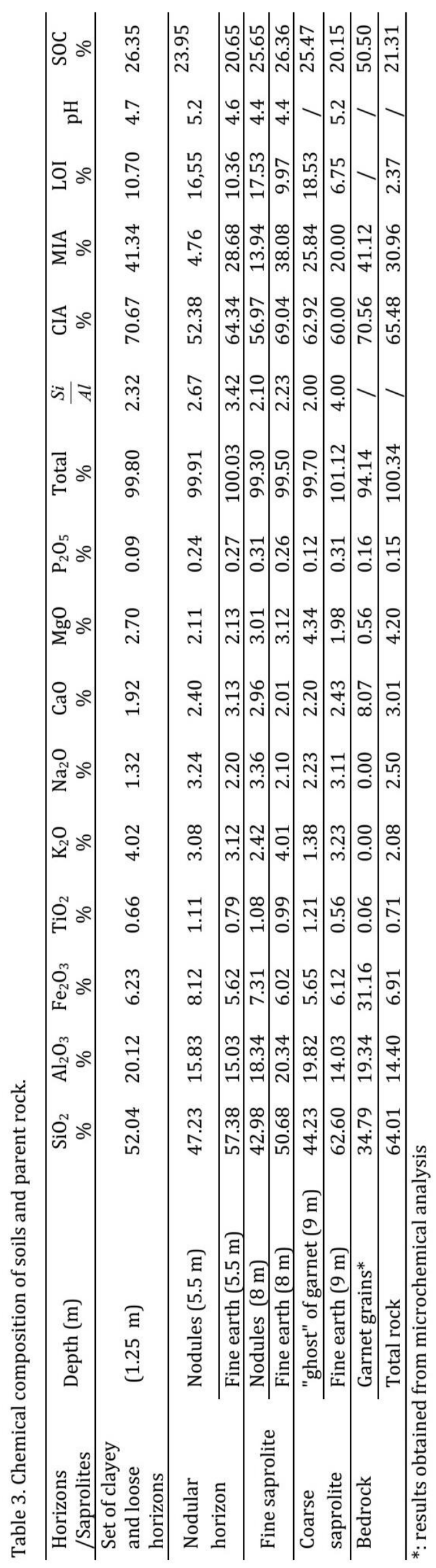




\section{Morphological evolution of weathering products}

Morphologically, the study profile is composed of two weathering materials: fine earth and nodules. Each material has a singular evolution from the coarse saprolite to the upper set of clayey and loose horizons.

The loose material or fine earth in the coarse saprolite is polychrome, sandy-loamy, characterized by a preserved bedrock structure and the presence of unweathered muscovite observed under polarized microscope (Figure 3). This material is transformed into a red clayey matrix with a very weakly developed blocky structure in the fine saprolite and a red clayey matrix with a fine blocky structure in the nodular horizon. In the set of red clayey and loose horizons, the fine earth is generalised and constitutes the essential part of the set of horizons (Figure 3). This set is characterized by a weakly expressed blocky structure at the bottom, a fluffy consistency symbolized by high matrix porosity in the median part and a fine blocky structure, and a dark red and shiny clay skins on some aggregates in the upper part, confirmed by typic coatings observed under the microscope (Figure 3). These three horizons are overlapped by a very dark red humiferous horizon with clay-sandy texture and weakly expressed lumpy structure.
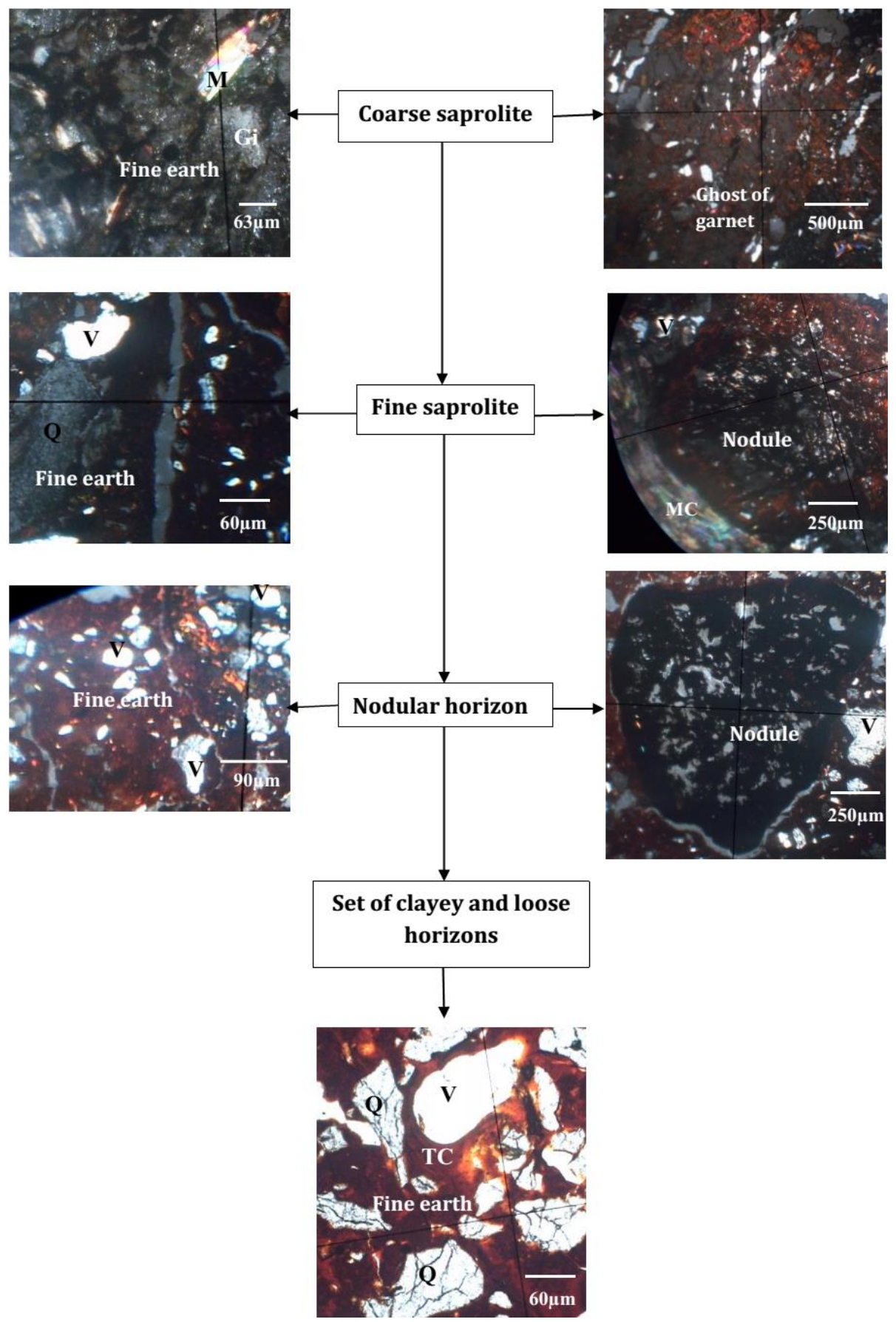

Figure 3. Microscopic observation of materials evolution in the studied profile (Q: quartz; M: muscovite; MC: micaceous cortex ; V : void; Gi: gibbsite; TC: typic coatings). 
On the other hand, there are numerous brown pink globular garnet crystals in the coarse saprolite characterized by a compartmentalized structure under the microscope, structure always noted in this mineral (Figure 3). Garnets are fractured and contain quartz and muscovite inclusions, and gibbsite crystallizations in microcraks and voids. They become slightly hardened in the fine saprolite and with a dark brown fracture and yellowish lining. This fracture shows a micaceous cortex visible under polarized microscope (Figure 3). Nodules become harder and have globally smooth and dark brown fractures, sometimes with whitish lining (Figure 3). Some fissures partially isolate those nodules from the micromass in the nodular horizon (Figure 3). They disappear progressively in the upper set.

\section{Bulk compositions of the studied soils and bedrock}

Selected major element- $\mathrm{Al}_{2} \mathrm{O}_{3}$ variation diagrams plotted on an anhydrous basis are given for each group in Figure 4. The elements plotted are the mobile species $\mathrm{CaO}, \mathrm{Na}_{2} \mathrm{O}$, and $\mathrm{K}_{2} \mathrm{O}$, along with $\mathrm{Fe}_{2} \mathrm{O}_{3}$ (total iron as $\mathrm{Fe}_{2} \mathrm{O}_{3}$ ), as a representative of a less mobile element, although Fe abundances may also be influenced by sesquioxide development. Two weathering trends are noted from the bedrock to the set of clayey and loose horizons (Figure 4). In fact, there is enrichment in $\mathrm{Al}_{2} \mathrm{O}_{3}$ in the fine earth concomitantly to enrichment in $\mathrm{Fe}_{2} \mathrm{O}_{3}, \mathrm{Na}_{2} \mathrm{O}$ and $\mathrm{K}_{2} \mathrm{O}$ in nodules (Figure 4). Globally, $\mathrm{Na}_{2} \mathrm{O}, \mathrm{K}_{2} \mathrm{O}, \mathrm{CaO}$ and $\mathrm{Fe}_{2} \mathrm{O}_{3}$ contents exhibit very weak correlations with $\mathrm{Al}_{2} \mathrm{O}_{3}$ (Figure 4). In detail, from the coarse saprolite to the upper set of red clayey and loose horizons, these elements are well correlated in nodules, confirming the two weathering trends noted. Abundances of these elements are in most cases much upper than in "fresh" rock indicating a weak substantial loss during weathering.
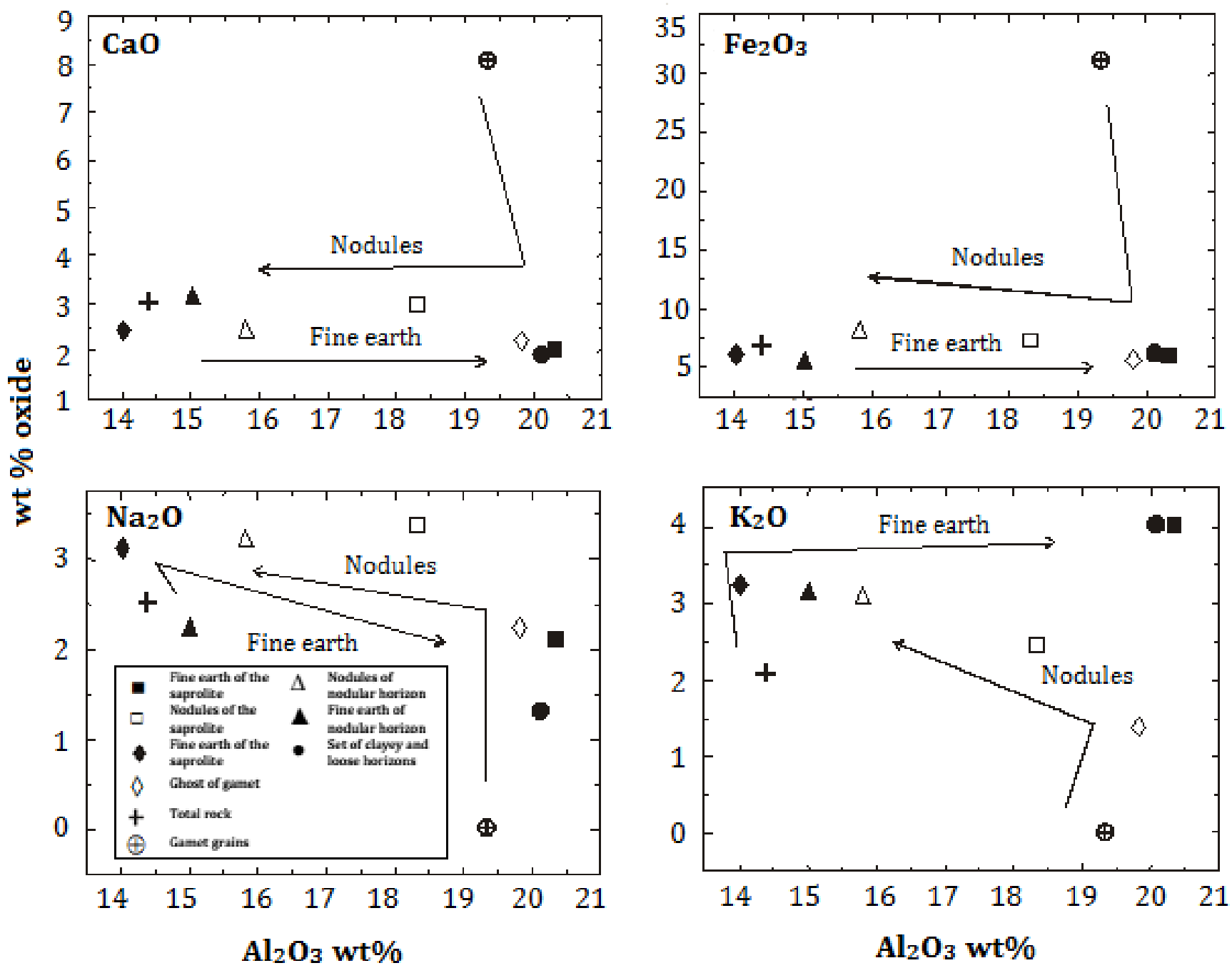

Figure 4. Major element- $\mathrm{Al}_{2} \mathrm{O}_{3}$ variation diagrams (anhydrous basis) for samples collected in the studied profile. 


\section{Evaluation of weathering trend}

Degradation of feldspar and concomitant formation of clay minerals is the dominant process during chemical weathering of the upper crust. Calcium, sodium and potassium are generally removed from feldspars, increasing the proportion of alumina to alkalis in the weathered product (Nesbitt and Young, 1982).

The ternary A-CN-K system is useful for evaluating the compositions of fresh plagioclase- and K-feldsparrich rocks and examining their weathering trends and their weathering products (clay minerals) (Nesbitt and Young, 1984, 1989; Fedo et al., 1995). The most intensely weathered samples plot in the top corner of the diagram, reflecting preponderance of Al-silicates. As plagioclase is more susceptible to weathering than $\mathrm{K}$-feldspar, and hence $\mathrm{Ca}$ and $\mathrm{Na}$ are leached preferentially over $\mathrm{K}$, the slopes of the trends should lie subparallel to the A-CN boundary as described in Nesbitt and Young (1989). Such trends intersect the A-K boundary once all plagioclase has been destroyed, and then trend toward the A apex because $\mathrm{K}$ is extracted from the residues in preference to $\mathrm{Al}$ (Aristizabal et al., 2005).

Rock samples and weathered samples plot globally far away from the feldspar join. They lie near the A-CN join, mostly toward the A apex, reflecting high concentrations of Al-bearing minerals (Figure 5). Two weathering trends are noted, materialized by two arrows which correspond to nodules and fine earth (Figure 5). The evolution of nodules from the garnet grain in the bedrock to the nodular horizon shows a progressively depletion in $\mathrm{Al}$, opposite to that observed in the fine earth.

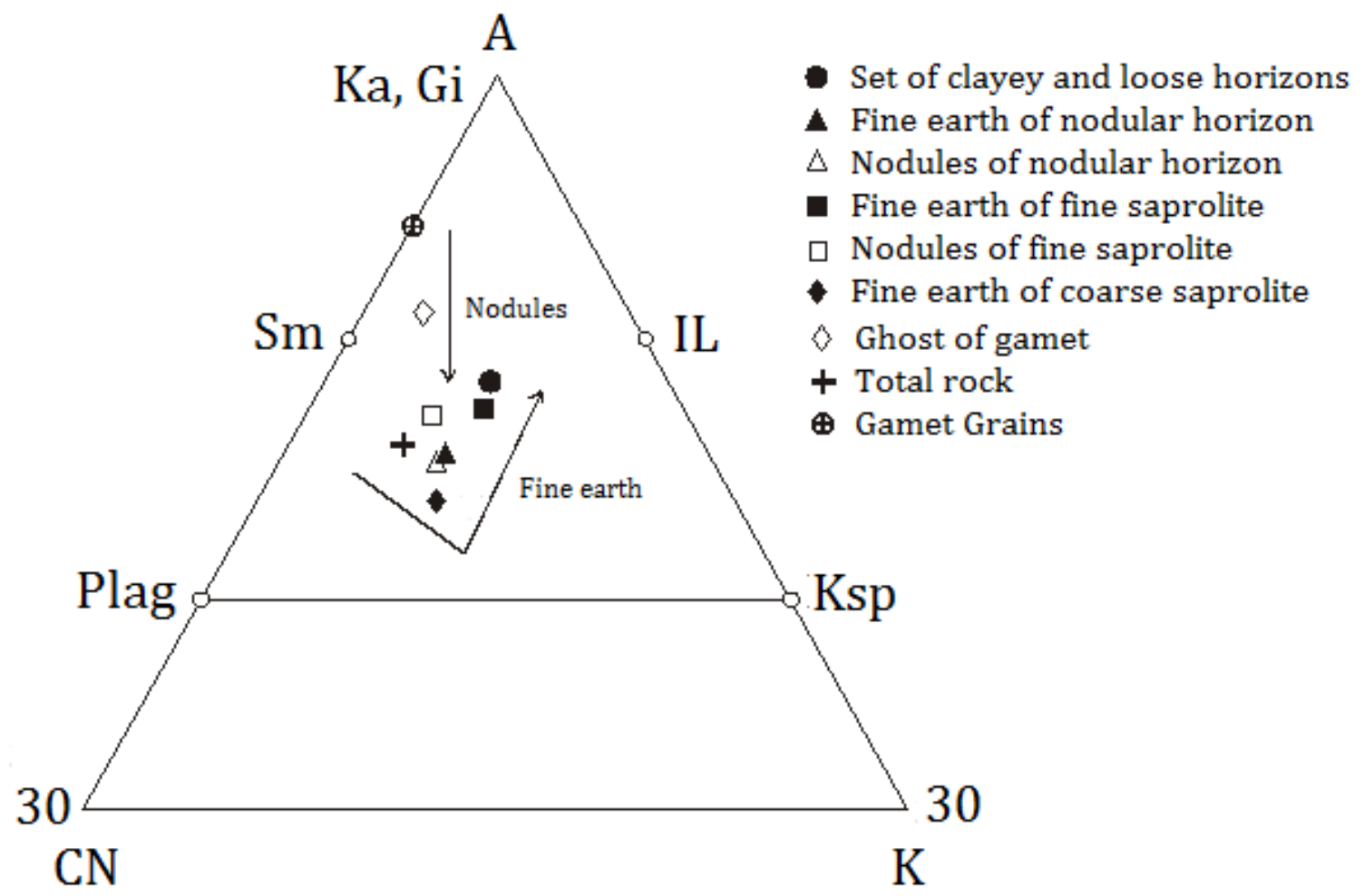

Figure 5. A-CN-K diagram illustrating the weathering trends of the studied soils.

A: $\mathrm{Al}_{2} \mathrm{O}_{3} ; \mathrm{K}: \mathrm{K}_{2} \mathrm{O} ; \mathrm{CN}$ : $\mathrm{CaO}^{*}+\mathrm{Na}_{2} \mathrm{O}$; Plag: plagioclase; Ksp : K-feldspar; Sm: smectite; IL: illite; Ka: kaolinite; Gi: gibbsite

(Nesbitt and Young, 1984; 1989).

Because $\mathrm{Mg}$ and $\mathrm{Fe}$ are potentially mobile in tropical environments, it is essential to also evaluate the chemical behaviour of these minerals in the weathering profiles (Nesbitt and Young, 1989). All samples plot on the tie line between feldspar (Fel) and the FM apex, lying globally parallel to A-CNK, both for nodules and fine earth. From the coarse saprolite to the upper set of clayey and loose horizons, there is a progressive depletion of $\mathrm{Al}$ in nodules concomitantly to an enrichment of this element in the fine earth (Figure 6). 


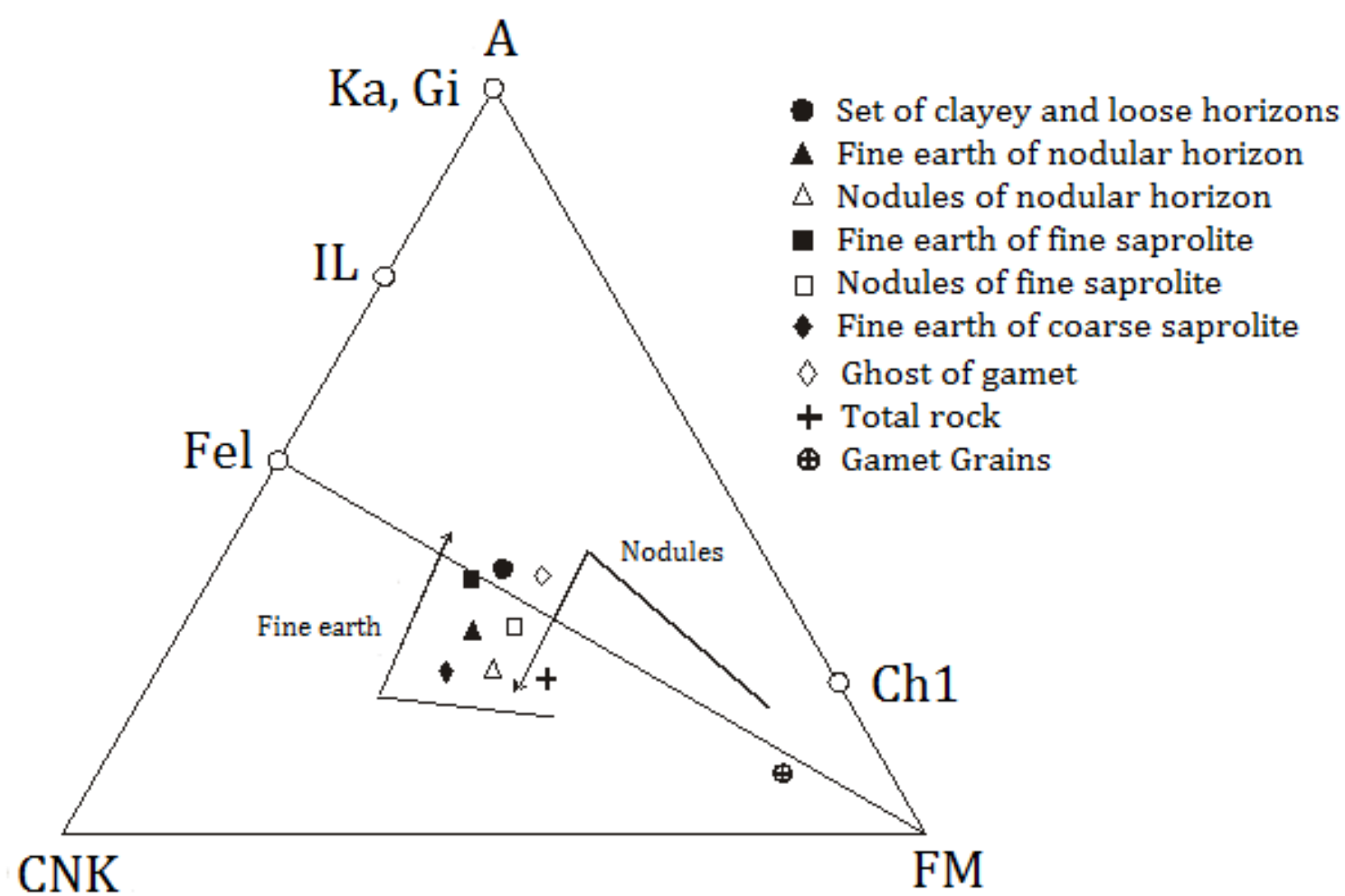

Figure 6. A-CNK-FM diagram illustrating the weathering trends of the studied soils.

A: $\mathrm{Al}_{2} \mathrm{O}_{3}$; $\mathrm{CNK}: \mathrm{CaO}^{*}+\mathrm{Na}_{2} \mathrm{O}+\mathrm{K}_{2} \mathrm{O}$; $\mathrm{FM}$ : $\mathrm{FeO}^{*}($ total FeO)+MgO; Fel: feldspar; Chl: chlorite; IL: illite; Ka: kaolinite; Gi: gibbsite (Nesbitt and Young, 1989; 1996).

\section{Evaluation of weathering intensity}

Many chemical indices are commonly used to evaluate the weathering intensity. Among them, there are $\mathrm{pH}$, loss on ignition (LOI), sesquioxide content (SOC), chemical index of alteration (CIA) and mineralogical index of alteration (MIA).

The chemical alteration index (CAI or CIA) is considered to be a good measure for the degree of weathering (Nesbitt and Young, 1982). Its calculation is based on molecular proportions:

$$
\mathrm{CIA}=\mathrm{Al}_{2} \mathrm{O}_{3} /\left(\mathrm{Al}_{2} \mathrm{O}_{3}+\mathrm{CaO} *+\mathrm{Na}_{2} \mathrm{O}+\mathrm{K}_{2} \mathrm{O}\right) \times 100
$$

In the equations, $\mathrm{CaO}^{*}$ is associated with the silicate fraction and corrected for inputs from carbonate and apatite (Ozaytekin and Uzun, 2012). Since $\mathrm{Al}$ is much more immobile than the alkali elements $\left(\mathrm{Na}^{+}\right.$and $\mathrm{K}^{+}$) and $\mathrm{Ca}^{2+}$, changes in CIA reflect changes in the proportions of feldspar and the various clay minerals developed in the soil profiles. The CIA values are directly represented on the A-CN edge of the A-CN-K triangle (Figure 7) as the elements involving this edge are the same as needed for the calculation of CIA. High CIA values reflect the removal of labile cations relative to stable residual constituents during weathering, and low CIA values indicate the near absence of chemical alteration (Nesbitt and Young, 1982). Chemical Index Alteration (CIA) values are directly represented on the $\mathrm{A}-\mathrm{CN}-\mathrm{K}$ triangle. The CIA corresponds to the horizontal projection on a vertical scale ranging from 0 (A-CN join) to 100 (A apex), where the fresh feldspar join has a value of 50 .

As indicated on figure 7, the samples can be subdivided into different weathering states according to their CIA values: residual soil, weathered/disintegrated material and rock discoloured by weathering to fresh rock. Globally, all samples are weathered (Figure 7). Around 50\% of material decomposed and/or disintegrated to soil, except for garnet grains and fine earth of coarse saprolite which position in the diagram might be due to absence of $\mathrm{K}_{2} \mathrm{O}$ and $\mathrm{Na}_{2} \mathrm{O}$ and high $\mathrm{Al}_{2} \mathrm{O}_{3}$ contents in garnet grains and the presence of muscovite in the fine earth of coarse saprolite (Figure 7). Globally, there are disparities between fine earth and nodules. CIA values in nodules increase from the nodular horizon to the bedrock (Table 3 and Figure 7). Nodules of the nodular horizon are less weathered than other nodules and garnet grain in the bedrock in line with observations already made by Tsozué et al. (2011). They are formed in situ and are stable in this environment of the humid tropical zone. 


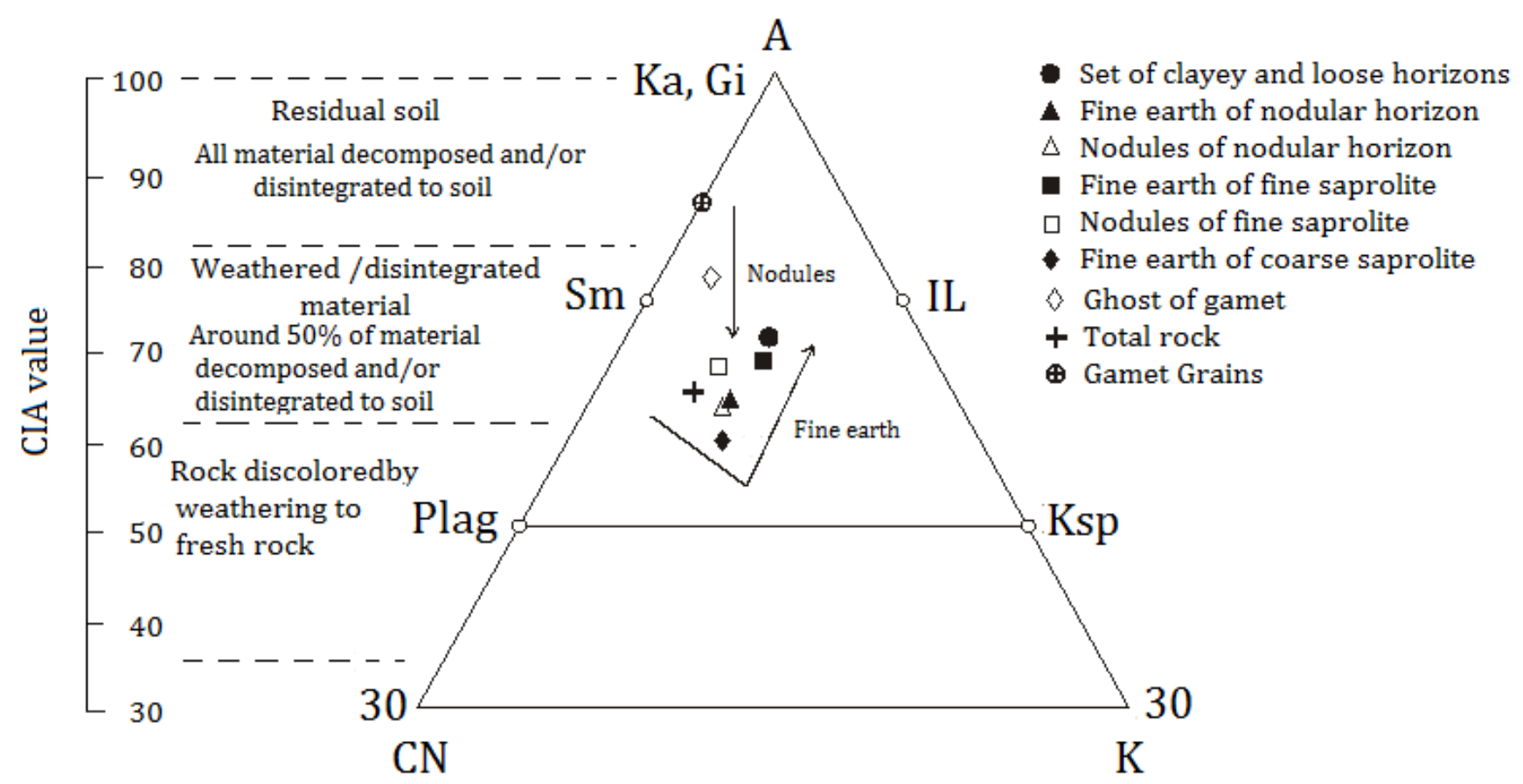

Figure 7. A-CN-K diagram illustrating weathering intensity (CIA values) of all samples collected from the studied profile. The CIA scale is divided into the simplified typical weathering profile described by the Geological Society of London in Lambe (1996).

As indicated on figure 7, the samples can be subdivided into different weathering states according to their CIA values: residual soil, weathered/disintegrated material and rock discoloured by weathering to fresh rock. Globally, all samples are weathered (Figure 7). Around 50\% of material decomposed and/or disintegrated to soil, except for garnet grains and fine earth of coarse saprolite which position in the diagram might be due to absence of $\mathrm{K}_{2} \mathrm{O}$ and $\mathrm{Na}_{2} \mathrm{O}$ and high $\mathrm{Al}_{2} \mathrm{O}_{3}$ contents in garnet grains and the presence of muscovite in the fine earth of coarse saprolite (Figure 7). Globally, there are disparities between fine earth and nodules. CIA values in nodules increase from the nodular horizon to the bedrock (Table 3 and Figure 7). Nodules of the nodular horizon are less weathered than other nodules and garnet grain in the bedrock in line with observations already made by Tsozué et al. (2011). They are formed in situ and are stable in this environment of the humid tropical zone.

The mineralogical index of alteration MIA evaluates the degree of mineralogical weathering. It is linked to CIA by the following relation:

$$
\text { MIA=2.(CIA-50) (Voicu et al., 1996). }
$$

MIA values obtained in the studied soil are between 0 and $41.34 \%$, indicating that they are incipient (0-20\%) to weak (20-40\%) and slightly moderately weathered (40-60\%), in line with the high presence of muscovites and micaceous cortex noted respectively in mineralogical analysis and under polarized microscope.

The sesquioxide content ( $\mathrm{SOC}$ ) reflects the $\mathrm{Fe}_{2} \mathrm{O}_{3}$ and $\mathrm{Al}_{2} \mathrm{O}_{3}$ content in a sample which are insoluble oxides (Irfan, 1996). An increase of SOC indicates either a higher intensity of leaching or oxidation resulting from the enrichment of ferric iron from the oxidation of ferrous iron (Ng et al., 2001). SOC values vary globally from 20 to $26 \%$ in the fine earth and from 23.95 to $25.65 \%$ in the nodules (Table 3 ). These values are highly influence by $\mathrm{Fe}_{2} \mathrm{O}_{3}$ content in the bedrock (31.16\% $\mathrm{Fe}_{2} \mathrm{O}_{3}$ in the garnet grains) (Table 3). The pH of the studied samples ranged from 4.4 to 5.2, indicating the very acid nature of the environment, favourable to the mobilization of basic cations.

Sueoka et al. (1985) proposed loss on ignition (LOI) as a good indicator of the degree of chemical weathering. In general, LOI increases as the intensity of weathering increases (Aristizábal et al., 2005). LOI values vary from $2.37 \%$ in the bedrock to $18.53 \%$ in the "ghost" of garnets of the coarse saprolite (Table 3 ). In detail, LOI values vary from $16.55 \%$ in the nodules of the nodular horizon to $18.53 \%$ in the ghost of garnet 
of the coarse saprolite, and in the opposite direction, from $2.37 \%$ in bedrock to $10.70 \%$ in the set of clayey and loose horizons (Table 3). LOI is less in fine earth and the total bedrock than in nodules (Table 3). As shown in figure 8, there is a very weak correlation between CIA and LOI in all the studied samples $\left(\mathrm{R}^{2}=0.23\right.$, Figure 8A). But in detail, there is a good correlation between CIA and LOI in the bedrock and fine earth of different horizons $\left(\mathrm{R}^{2}=0.70\right.$, Figure $\left.8 \mathrm{~B}\right)$ and in nodules from the coarse saprolite to the nodular horizon $\left(\mathrm{R}^{2}=\right.$ 0.99, Figure 8C).
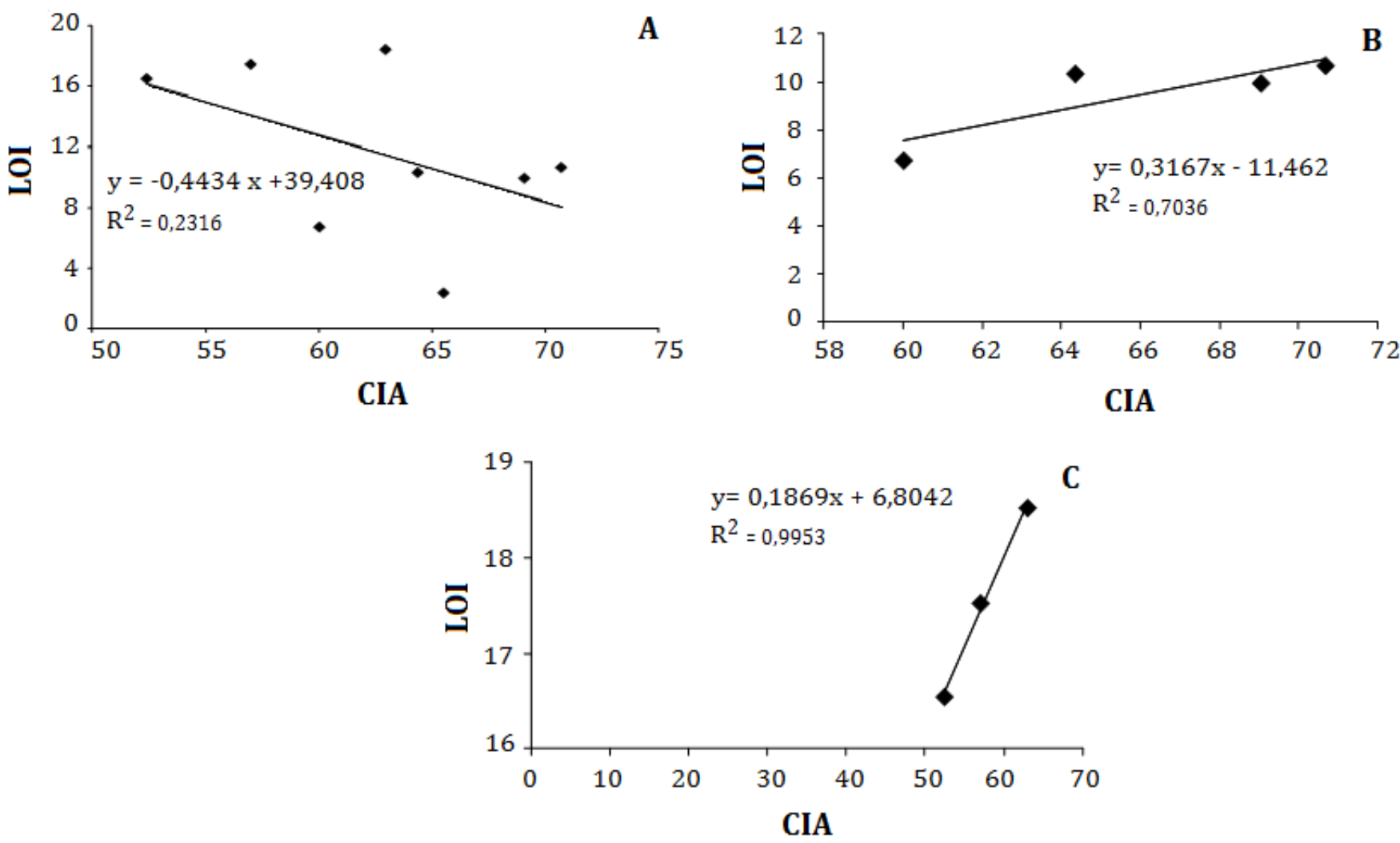

Figure 8. CIA-LOI graph

(A: whole rock and weathering products; B- fine earth of loose horizons; C: nodules of loose horizons).

\section{Mass balance}

In the fine earth, $\mathrm{Si}$ and $\mathrm{Fe}$ are depleted out of the profile. Their mobilization rates fluctuated respectively, from $-43 \%$ in the fine saprolite to $24 \%$ in the coarse saprolite and from $-38 \%$ in the set of clayey and loose horizons to $12 \%$ in the coarse saprolite. The mean values are $-13 \%$ for $\mathrm{Si}$ and $-14 \%$ for Fe, which correspond respectively, to a total mobilized mass of -0.812 and $-0.095 \mathrm{~g} / \mathrm{cm}^{3}$ (Tables 4 and 5). $\mathrm{Al}$, on the other hand, is imported in the fine earth of the studied profile. Its mobilization rate varies between $-6 \%$ in the nodular horizon and $51 \%$ in the set of clayey and loose horizons (Table 4), thus a mean value of $18.5 \%$ corresponding to a total mobilized mass of $0.247 \mathrm{~g} / \mathrm{cm}^{3}$ (Table 5). This accumulation of $\mathrm{Al}$ in the fine earth already noted in major element- $\mathrm{Al}_{2} \mathrm{O}_{3}$ variation diagrams corresponds to an "aluminization" process.

Table 4. Bulk density and element mobilization ratios in the fine earth of the studied soils.

\begin{tabular}{|c|c|c|c|c|c|}
\hline $\begin{array}{ll}\text { Horizons } & \mathrm{Db}, \varepsilon, \tau \\
\end{array}$ & da $\left(\mathrm{g} / \mathrm{cm}^{3}\right)$ & $\varepsilon-\mathrm{Ti}$ & $\tau \mathrm{Si}$ & $\tau \mathrm{Al}$ & $\tau \mathrm{Fe}$ \\
\hline Set of clayey and loose horizons & 1,5 & 0,79 & $-0,12$ & 0,51 & $-0,03$ \\
\hline Nodular horizon & 0,85 & 1,63 & $-0,20$ & $-0,06$ & $-0,27$ \\
\hline Fine saprolite & 0,87 & 1,05 & $-0,43$ & 0,01 & $-0,38$ \\
\hline Coarse saprolite & 1,4 & 1,25 & 0,24 & 0,23 & 0,12 \\
\hline Bedrock & 2,49 & 0 & 0 & 0 & 0 \\
\hline
\end{tabular}

Db: bulk density; $\varepsilon$-Ti: deformation ratio at Ti constant; $\tau$ : relative enrichment ratio of an element in comparison with the bedrock. 
Table 5. Mobilized mass (m) of elements in the fine earth of the studied soils $\left(\mathrm{g} / \mathrm{cm}^{3}\right)$.

\begin{tabular}{lccc}
\hline Horizons & $\mathrm{mSi}$ & $\mathrm{mAl}$ & $\mathrm{mFe}$ \\
\hline Set of clayey and loose horizons & $-0,191$ & 0,183 & $-0,005$ \\
Nodular horizon & $-0,319$ & $-0,022$ & $-0,046$ \\
Fine saprolite & $-0,685$ & 0,004 & $-0,065$ \\
Coarse saprolite & 0,383 & 0,082 & 0,021 \\
Sum & $-0,812$ & 0,247 & $-0,095$ \\
\hline
\end{tabular}

In the nodules, all the three elements are depleted out of the profile. Their mobilization rates vary from -30 to $17 \%$ for $\mathrm{Si},-38$ to $-13 \%$ for $\mathrm{Al}$ and -13 to $57 \%$ for Fe (Table 6 ), thus mean values of $-6.50 \%$ for $\mathrm{Si},-25.5 \%$ for $\mathrm{Al}$ and $22 \%$ for Fe (Table 6). These correspond respectively, to a total mobilized mass of $-0.253,-0.444$ and $0.109 \mathrm{~g} / \mathrm{cm}^{3}$ (Table 7). The depletion of Al corresponds to a "desaluminization" process. The higher depletion rate of $\mathrm{Fe}$ is mostly from the bedrock to the coarse saprolite. Here, $\mathrm{Fe}_{2} \mathrm{O}_{3}$ contents decrease from $31.16 \%$ in the garnet of the bedrock to $5.65 \%$ in the "ghost" of garnet of the coarse saprolite (Table 3). From the coarse saprolite to the nodular horizon, this content increases from 5.65\% to 8.12\% (Table 3), corresponding to an accumulation rate of $22 \%$, thus, leading to the densification and the formation of nodules with dark undifferentiated micromass of hematitic nature in their inner part in the nodular horizon (Figure 3), characteristic of a ferruginization process.

Table 6. Bulk density and element mobilization ratios in the nodules of the studied soils.

\begin{tabular}{|c|c|c|c|c|c|}
\hline $\begin{array}{ll}\text { Horizons } & \mathrm{Db}, \varepsilon, \tau \\
\end{array}$ & $\begin{array}{c}\mathrm{Db} \\
\left(\mathrm{g} / \mathrm{cm}^{3}\right)\end{array}$ & $\varepsilon-\mathrm{Ti}$ & $\tau \mathrm{Si}$ & $\tau \mathrm{Al}$ & $\tau \mathrm{Fe}$ \\
\hline Nodular horizon & 2,36 & 1,03 & 0,17 & $-0,13$ & 0,57 \\
\hline Fine saprolite & 3,18 & $-0,07$ & $-0,30$ & $-0,38$ & $-0,13$ \\
\hline Coarse saprolite & 4,39 & 0 & 0 & 0 & 0 \\
\hline
\end{tabular}

Db: bulk density; $\boldsymbol{\varepsilon}$-Ti: deformation ratio at Ti constant; $\boldsymbol{\tau}$ : relative enrichment ratio of an element in comparison with the bedrock.

Table 7. Mobilized mass (m) of elements in the nodules of the studied soils $\left(\mathrm{g} / \mathrm{cm}^{3}\right)$.

\begin{tabular}{lccc}
\hline Horizons & Elements & $\mathrm{mSi}$ & $\mathrm{mAl}$ \\
\hline Nodular horizon & 0,330 & $-0,113$ & $\mathrm{mFe}$ \\
Fine saprolite & $-0,583$ & $-0,331$ & $-0,032$ \\
Sum & $-0,253$ & $-0,444$ & 0,109 \\
\hline
\end{tabular}

\section{Discussion}

Tropical chemical weathering in the studied soil leads to the decomposition of the entire primary mineral except muscovite and quartz, promoting the development of a very thick soil profile $(>10 \mathrm{~m})$ composed of kaolinite, gibbsite, aluminous goethite, hematite and traces of anatase. The first stage of garnet-rich micaschist weathering corresponds to a more or less isovolumentric process, with preservation of the overall fabric of the rock. This suggests in situ replacement of primary minerals by kaolinite and gibbsite, confirmed by microscopic observations. The presence of kaolinite in the saprolite characterizes the more advanced stages of weathering, and the intensive tropical weathering is reflected in the formation of iron and aluminum sesquioxides, goethite and gibbsite (Aristizábal et al., 2005).

Garnet minerals specifically, undergo congruent dissolution, leading progressively to replacement of garnet grains by goethite-gibbsite pseudomorphs in the fine saprolite, and the formation of alteromorph nodules described by Stoops (2003). These alteromorph nodules are characterized by the total absence of relicts of original garnet grains, the presence of ferruginous yellowish brown and very birefringent intragranular fracture coatings, essentially of goethite nature, and the maintenance of discontinuous "micaceous cortex" which marks the original flow structures of the original bedrock. Nodules observed in fine saprolite show no etch pits and their surfaces are regular, evidence of well preservation in this environment of the rainforest zone of Southern Cameroon. Ultimately, in the nodular horizon, nodules are pseudomorphosed completely by iron oxides, with however a presence of gibbsite. They show a dark undifferentiated micromass of haematitic nature in their inner part, and globally, there is a development of fissures which partially isolate those nodules from the micromass. This evolution of nodules from the coarse saprolite to the nodular 
horizon is concomitant to a high depletion of $\mathrm{Al}_{2} \mathrm{O}_{3}$ and an increase in $\mathrm{Fe}_{2} \mathrm{O}_{3}$ contents from the coarse saprolite to nodular horizon, meaning that conditions are favourable to the stabilisation of iron oxides, corresponding to the ferruginization process already described by Beauvais and Collin (1993). This stabilisation and accumulation of iron under acid environment was also reported by Marquez et al. (2004) in Brazilian Cerrado soils. This ferruginization process might be due to accumulation of hematite in the small pores in a pre-existing kaolinite accumulation (Tardy and Nahon, 1985; Beauvais, 1999), resulting from a decrease of water activity and of atmospheric relative humidity, and from a temperature increase (Tardy et al., 1991). The formation of nodules obtained here is similar to that of the "first generation nodules" studied by Yongue-Fouateu (1986) in the soil profile of Ekoumdoum developed on garnet-rich migmatitic gneiss in the Yaoundé region, situated at $740 \mathrm{~m}$ a.s.l. The author noted the disappearance of gibbsite and the increase of iron contents in the lithorelictual intragranular groundmass of garnet pseudomorphs. The stability of garnet pseudomorph and their individualization in the form of nodules was also reported by Embrechts and Stoops (1982) in Cameroon (Yaoundé) and Parisot et al. (1983) in Brazil. The formation process of the studied nodules is fundamentally different from that of the "second generation nodules" frequently studied by authors in the humid tropical zone, which derive from the degradation of iron duricrust (Beauvais and colin, 1993; Beauvais and Tardy, 1993; Beauvais, 2009; Tsozué et al., 2012). Contrary to the studied soils, the two generations of nodules are present in the Ekoumdoum soil profile, developed on garnet-rich migmatitic gneiss (Figure 9). However, "second generation" nodules are more frequent in humid tropical zone (Tardy, 1993; Beauvais and colin, 1993; Beauvais and Tardy, 1993; Temgoua et al., 2002; Bitom et al., 2004; Beauvais, 2009; Tsozué et al., 2012).

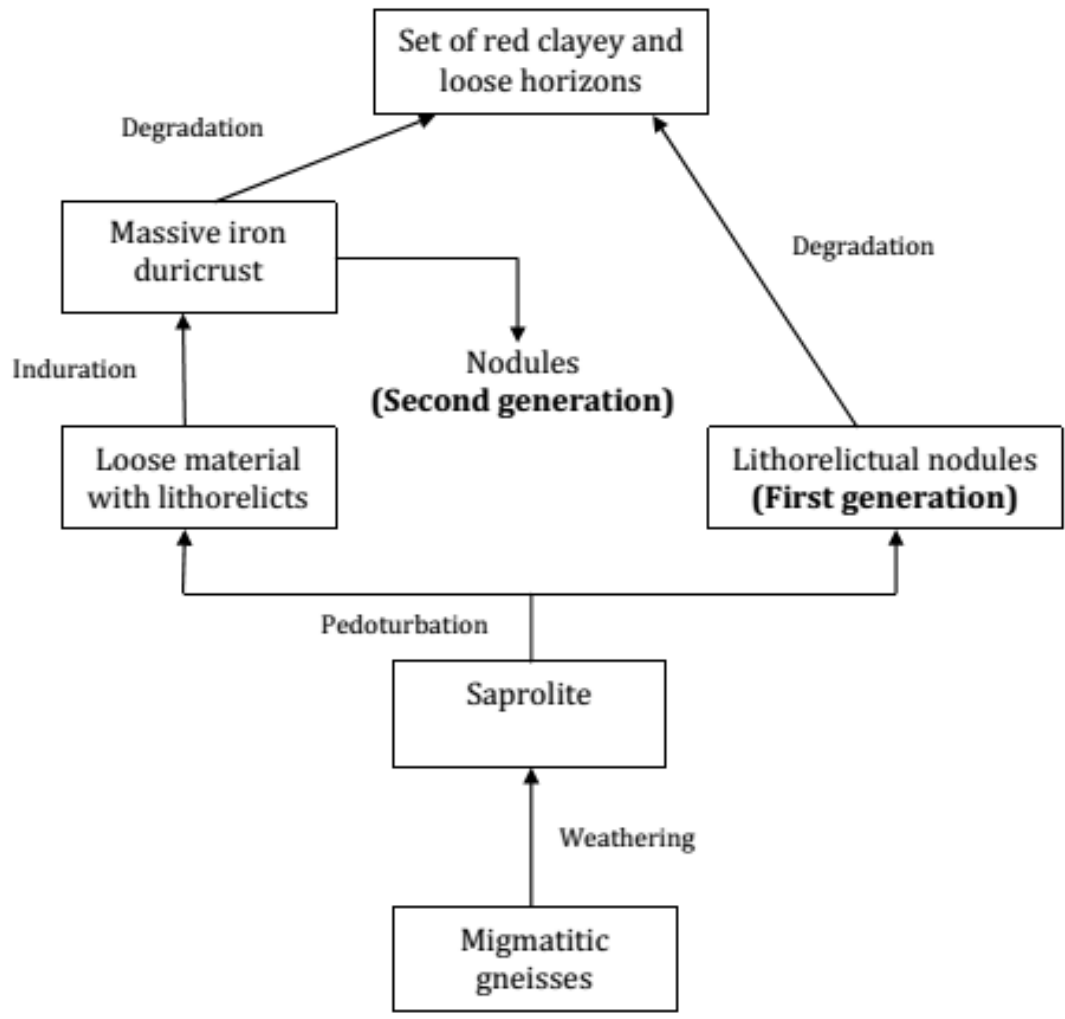

Figure 9. Filiations in the soil profile of Ekoumdoum (Yongue-Fouateu, 1986).

Beside the garnet grain, other primary minerals exhibit an opposite evolution. Intensive tropical weathering leads to their complete decomposition into fine earth. The evolution of the groundmass of this fine earth from the saprolite to the set of clayey and loose horizons is mainly structural, through the reorganization of the reddish clayey ferruginous micromass (Yongue-Fouateu, 1986). In relation with this reorganization, the porosity increase, giving rise to clayey ferruginous typic coating deposit noted in the upper part of the set of clayey and loose horizons. The set of red clayey and loose horizons observed here on top of the nodular horizon might derive from the generalization of the internodular red clayey matrix, in addition to the fine earth generated by the degradation of nodules. The fine earth is composed of kaolinite, gibbsite, goethite, hematite, anatase, muscovite and quartz. The formation of kaolinite may derive from the late weathering of micas if the water activity in matrix pores is $\leq 0.9$ (Beauvais, 2009), but hematite could remain stable (Trolard and Tardy, 1987). Both micas and kaolinite may however transform into gibbsite if the water 
activity is $>0.9$ (Tardy, 1993), and the hematite is dissolved and partly transformed into goethite at the base of the studied profile (Trolard and Tardy, 1987). Globally, there is $\mathrm{Al}_{2} \mathrm{O}_{3}$ enrichment in the fine earth concomitantly to $\mathrm{Fe}_{2} \mathrm{O}_{3}$ depletion. In fact, within the studied profile, biological activity might provide more reducing conditions (Beauvais and Tardy, 1993; Beauvais, 2009). At the upper part of the profiles, within the humic layer, the weathering solutions are loaded with reducing anions such as $\mathrm{SO}_{4}{ }^{2-}, \mathrm{NO}_{3}{ }^{-}, \mathrm{PO}_{4}{ }^{3-}$ and $\mathrm{Cl}$, which decrease Eh and $\mathrm{pH}$ and thus lead to iron leaching (Beauvais and Tardy, 1993), and consequently to a progressive accumulation of $\mathrm{Al}_{2} \mathrm{O}_{3}$ in the fine earth.

Three pedogenetic processes emerge from the evolution of weathering products derived from the studied garnet-rich micaschist. There is a ferruginization process whose intensity increases from the coarse saprolite to the upper set of clayey and loose horizons, giving rise to the formation of dense nodules with dark undifferentiated micromass, composed of hematite, goethite and gibbsite. This ferruginization occurs concomitantly to a desaluminization process, which cause a high depletion of $\mathrm{Al}_{2} \mathrm{O}_{3}$ in nodules, with a mobilization mass of $-0.444 \mathrm{~g} / \mathrm{cm}^{3}$. These nodules are formed by the process of induration in which the hydrated amorphous hydroxide and oxides are dehydrated to their crystalline oxide form, due to condensation, leading thus to the development of stable inert aggregate units in the soil, containing hematite and gibbsite minerals (Sherman et al., 1969). In addition, there is an aluminization process, which occurs in the fine earth, leading to the development of a red clayey material constituted of kaolinite and gibbsite. These processes which occurs in opposite direction, materialized by two trends in major element- $\mathrm{Al}_{2} \mathrm{O}_{3}, \mathrm{~A}-$ $\mathrm{CN}-\mathrm{K}$ and A-CNK-FM diagrams, operate continuously under acidic conditions in the humid tropical rainforest of Southern Cameroon. The acidic conditions are maintained perhaps by high organic activity (Jayant et al., 2007), leading thus to the development and the differentiation of the studied soils.

\section{Conclusion}

The main objective of this study was to investigate weathering trends and weathering intensity, chemical behavior of major elements and improve the understanding of the different weathering processes occurring during the decomposition and/or the transformation of the garnet-rich micaschist in Southern Cameroon. Morphologically, two weathering materials constituted the studied profile. They are fine earth and nodules. Each material has a singular evolution from the coarse saprolite to the upper set of clayey and loose horizons. Around $50 \%$ of material decomposed and/or disintegrated to soil, except for garnet grains and fine earth of coarse saprolite which might be due to absence of $\mathrm{K}_{2} \mathrm{O}$ and $\mathrm{Na}_{2} \mathrm{O}$ and high $\mathrm{Al}_{2} \mathrm{O}_{3}$ contents in garnet grains and the presence of muscovite in the fine earth of coarse saprolite. CIA values in nodules increase from the nodular horizon to the bedrock. Nodules of the nodular horizon are less weathered than other nodules and garnet grain in the bedrock. SOC values vary globally from 20 to $26 \%$ in the fine earth and from 23.95 to $25.65 \%$ in the nodules. The $\mathrm{pH}$ of the studied samples ranged from 4.4 to 5.2 , indicating the very acid nature of the environment, favourable to the mobilization of basic cations. LOI values vary from $2.37 \%$ in the bedrock to $18.53 \%$ in the "ghost" of garnets of the coarse saprolite. In detail, LOI values vary from $16.55 \%$ in the nodules of the nodular horizon to $18.53 \%$ in the ghost of garnet of the coarse saprolite, and in the opposite direction, from $2.37 \%$ in bedrock to $10.70 \%$ in the set of clayey and loose horizons, in the fine earth. The evolution of nodules from the coarse saprolite to the nodular horizon is concomitantly to a high $\mathrm{Al}_{2} \mathrm{O}_{3}$ depletion and an increase in $\mathrm{Fe}_{2} \mathrm{O}_{3}$ contents from the coarse saprolite to nodular horizon, characteristic of desaluminization process. This process occurs together with ferruginization process, giving rise to the formation of nodules with dark haematitic undifferentiated micromass in the nodular horizon. On the other hand, there is an aluminization process which occurs in the fine earth, leading to the development of a red clayey material constituted of kaolinite and gibbsite. These three processes occur together, leading to the weathering of the garnet-rich micaschist and the development and the differentiation of the studied soils.

\section{Acknowledgements}

The authors thank Dr Azinwi Tamful Primus for his critical comments and suggestions on this paper. We are also glad for the comments and suggestions of the anonymous referees who have substantially improved the quality of this paper.

\section{References}

Anderson, S.P., Dietrich, W.E., Brimhall, G.H., 2002. Weathering profiles, mass-balance analysis, and rates of solute loss: linkages between weathering and erosion in a small, steep catchment. GSA Bulletin 114(9): 1143-1158.

Aristizabal, E., Roser, B., Yokota, S., 2005. Tropical chemical weathering of hillslope deposits and bedrock source in the Aburra Valley, northern Colombian Andes. Engineering Geology 81(4): 389-406. 
Beauvais, A., 1999. Geochemical balance of lateritization processes and climatic signatures in weathering profiles overlain by ferricretes in Central Africa. Geochimica et Cosmochimica Acta 63(23-24): 3939-3957.

Beauvais, A., 2009. Ferricrete biochemical degradation on the rainforest-savannas boundary of Central African Republic. Geoderma 150(3-4): 379-388.

Beauvais, A., Colin, F., 1993. Formation and transformation processes of iron duricrust systems in tropical humid environment. Chemical Geology 106(1-2): 77-151.

Beauvais, A., Tardy. Y., 1993. Degradation and dismantling of iron crusts under climatic changes in Central Africa. Chemical Geology 107(3-4): 277-280.

Bitom, D., Volkoff, B., Beauvais, A., Seyler, F., Ndjigui, P.D., 2004. Rôle des héritages latéritiques et du niveau des nappes dans l'évolution des modelés et des sols en zone intertropicale forestière humide. Comptes Rendus Geoscience 336(13): 1161-1170.

Brimhall, G.H., Alpers, C.N., Cunningham, A.B., 1985. Analysis of supergene ore-forming processes and ground-water solute transport using mass balance principles. Economic Geology 80(5): 1227-1256.

Brimhall, G.H., Dietrich, W.E., 1987. Constitutive mass balance relations between chemical composition, volume, density, porosity and strain in metasomatic hydrochemical systems: results on weathering and pedogenesis. Geochimica et Cosmochimica Acta 51(3): 567-587.

Brimhall, G.H., Lewis, C.J., Ague, J.J., Dietrich, W.E., Hampel, J., Teague, T., Rix, P., 1988. Metal enrichment in bauxites by deposition of chemically mature aeolian dust. Nature 333: 819-824.

Colin, F., Brimhall, G.H., Nahon, D., Lewis, C.J., Baronnet A., Danty, K., 1992. Equatorial rainforest lateritic mantles: a geomembrane filter. Geology 20(6): 523-526.

Colin, F., Viellard, P., Ambrosi, J.P., 1993. Quantitative approach to physical and chemical gold mobility in equatorial rain forest lateritic environment. Earth and Planetary Science Letters 114(2-3): 269-285.

Davy, R., El Ansary, M., 1986. Geochemical patterns in the laterite profile at the Boddington gold deposit, Western Australia. Journal of Geochemical Exploration 26(2): 119-124.

Deepthy, R., Balakrishnan, S., 2005. Climatic controle on clay mineral formation: Evidence from weathering profiles developed on either side of the Western Ghats. Journal of Earth System Science 114(5): 545-556.

Duzgoren-Aydin, N.S., Aydin, A., Malpas, J., 2002. Distribution of clay minerals along a weathered pyroclastic profile, Hong Kong. Catena 50(1): 17-41.

Embrechts, J., Stoops, G., 1982. Microscopical aspects of garnet weathering in humid tropical environment. European Journal of Soil Science 33: 535-545.

Fedo, C.M., Nesbitt, H.W., Young, G.M., 1995. Unraveling the effects of potassium metasomatism in sedimentary rocks and paleosols, with implications for paleoweathering conditions and provenance Geology 23(10): 921-924.

Gupta, A., Rao, K., 2001. Weathering indices and their applicability for crystalline rocks. Bulletin of Engineering Geology and the Environment 60(3): 201- 221.

Helgren, D.M., Butzer, K.W., 1977. Paleosols of the Southern Cape Coast, South Africa: Implications for laterite definition, genesis and age. Geographical Review 67(4): 430-445.

Irfan, T.Y., 1996. Mineralogy, fabric properties and classification of weathered granites in Hong Kong. Quaterly Journal of Engineering Geology and Hydrogeology 29(1): 5-35.

Irfan, T.Y., 1999. Characterization of weathered volcanic rocks in Hong Kong. Quaterly Journal of Engineering Geology and Hydrogeology 32: 317-348.

Jayant K. Tripathi, V., Rajamani, 2007. Geochemistry and origin of ferruginous nodules in weathered granodioritic gneisses, Mysore Plateau, Southern India. Geochimica et Cosmochimica Acta 71(7): 1674-1688.

Kamgang, K.B.V., Onana, V.L., Ndome, E.E.P., Parisot, J.C., Ekodeck, G.E., 2009. Behaviour of REE and mass balance calculations in a lateritic profile over chlorite schists in South Cameroun. Chemie der Erde - Geochemistry 69(1): 61-73.

Lambe, P., 1996. Residual soils. Landslides: investigation and mitigation. In: Turner, K., Schuster, R. (Eds.), Landslides Investigation and Mitigation, Special Report, Transportation Research Board, National Research Council, vol. 247, pp. 507- 524 .

Letouzey, R., 1985. Notice explicative de la carte phytogéographique du Cameroun à l'échelle de 1/500 000. Institut de la Carte Internationale de la Végétation, Toulouse, France., 240p.

Marques, J.J., Schulze, D.G., Curi, N., Mertzman, S.A., 2004. Trace element geochemistry in Brazilian Cerrado soils. Geoderma 121(1-2): 31-43.

McFarlane, M.J., 1976. Laterite and Landscape. Academic Press, London, 151 p.

Nahon, D., 1991. Introduction to the Petrology of Soils and Chemical Weathering. John Wiley, New York, 313p.

Nahon, D., 2003. Weathering in tropical zone. Significance through ancient and still active mechanisms. Comptes Rendus Géoscience 335(16): 1109-1119.

Ndjigui, P.-D., Badinane, M.F.B., Nyeck, B., Nandjip, H.P.K., Bilong, P., 2013. Mineralogical and geochemical features of the coarse saprolite developed on orthogneiss in the SW of Yaoundé, South Cameroon. Journal of African Earth Sciences 79: 125-142. 
Ndjigui, P.D., Bilong, P., Bitom, D., Dia, A., 2008. Mobilization and redistribution of major and trace elements in two weathering profiles developed on serpentinites in the Lomié ultramafic complex, South-East Cameroon. Journal of African Earth Sciences 50(5): 305-328.

Nesbitt, H.W., Young, G.M., 1982. Early Proterozoic climates and plate motions inferred from major element chemistry of lutites. Nature 279: 715-717.

Nesbitt, H.W., Young, G.M., 1984. Prediction of some weathering trends of plutonic and volcanic rocks based on thermodynamic and kinetic considerations. Geochimica et Cosmochimica Acta 48(7): 1523-1534.

Nesbitt, H.W., Young, G.M., 1989. Formation and diagenesis of weathering profiles. Journal of Geology 97(2): 129-147.

Nesbitt, H.W., Young, G.M., McLennan, S.M., Keays, R.R., 1996. Effects of chemical weathering and sorting on the petrogenesis of siliciclastic sediments, with implication for provenance studies. Journal of Geology 104(5): 525542.

Ng, C.W.W., Guan, P., Shang, Y.J., 2001. Weathering mechanisms and indices of igneous rocks of Hong Kong. Quaterly Journal of Engineering Geology and Hydrogeology 34(2): 133-151.

Nguetnkam, J.P., Kamga, R., Villiéras, F., Ekodeck, G.E., Yvon, J., 2008. Variable weathering response of granite in tropical zones. Example of two sequences studied in Cameroon (Central Africa). Comptes Rendus Geoscience 340(7): 451461.

Ozaytekin, H.H., and Uzum, C., 2012. Comparison of weathering rates of the soils classiefied in Alfisol and Entisol order developed on limestone in the Taurus Mountains at East Mediterranean region. Carpathian journal of Earth and Environmental Sciences 7(1): 109-120.

Parisot, J.C., Delvigne, J., Groke, M.C.T., 1983. Petrographical aspects of the supergene weathering of garmet in the "Serra dos Carajas" (Para, Brasil). Mémoires Sciences Géologiques 72 : 141-148.

Price, J.R., Velbel, M.A., 2003. Chemical weathering indices applied to weathering profiles developed on heterogeneous felsic metamorphic parent rocks. Chemical Geology 202(3-4): 397- 416.

Sherman, D.G., Ikawa, H., and Matsusaka, Y., 1969. Aluminous-ferruginous oxide mineral nodules in tropical soils. Pacific Science 23: 115-122.

Stoops, G., 2003. Guidelines for analysis and description of soil and regolith thin sections. Soil Society of America, INC., Madison, USA, 184p.

Suchel, J.-B., 1987. Les climats du Cameroun. Thesis. Université de Bordeaux III, France, 1186p.

Sueoka, T., Lee, I.K., Huramatsu, M., and Imamura, S., 1985. Geomechanical properties and engineering classification for decomposed granite soils in Kaduna district, Nigeria.. First International Conference of Geomechanics in tropical laterititc and saprolitc soils, Brasilia, 1: 175-186.

Tardy, Y., 1993. Pétrologie des latérites et des sols tropicaux. Masson, Paris, 459 p.

Tardy, Y., and Roquin, C., 1998. Dérive des continents, Paléoclimats et altérations tropicales. BRGM editions, Orléans, France, 431p.

Tardy, Y., Kobilsex, B., Paquet, H., 1991. Mineralogical composition and geographical distribution of African and Brazilian periatlantic laterites. The influence of continental drift and tropical paleoclimates during the past 150 million years and implications for India and Australia. Journal of African Earth Sciences (and the Middle East) 12(1/2): 283-295.

Tardy, Y., Nahon., D., 1985. Geochemistry of laterites, stability of Al-Goethite, Al-Hematite and F ${ }^{3+}$ Kaolinite in bauxites and ferricretes: an approach to the mechanism of concretion formation. American Journal of Science 285(10): 865-903.

Temgoua, E., 2001. Les accumulations ferrugineuses actuelles de bas versant en zone forestière humide du SudCameroun. Evolutions pétrologiques des faciès et des éléments en traces en relation avec le cuirassement. Th. Doc., Université Lausanne, 165p.

Temgoua, E., Bitom, D., Bilong, P., Lucas, Y., Pfeifer, H. R., 2002. Démantèlement des paysages cuirassés anciens en zone forestière tropicale d'Afrique Centrale, formation d'accumulations ferrugineuses actuelles au bas des versants. Comptes Rendus Geoscience 334 (8) : 537-543.

Thiel, R., 1963. Zum system. FeOOH - AlOOH. Zeitschrift für anorganische und allgemeine Chemie 326(1-2) : 70-78.

Thomas, M.F., 1994. Geomorphology in the tropics. A Study of weathering and denudation in low latitudes. John Wiley \& Sons., Chichester, $460 \mathrm{p}$

Trolard, F.,Tardy, Y., 1987. The stabilities of gibbsite, boehmite, aluminous goethites and aluminous hematites in bauxites, ferricretes and laterites as a function of water activity, temperature and particle size. Geochimica et Cosmochimica Acta 51(4): 945-957.

Tsozué, D., Bitom D., Yongue-Fouateu, R., 2011. In Situ Genesis of Alumino-Ferruginous Nodules in a Soil Profile Developed on Garnet Rich Micaschist in the High Reliefs of South Cameroon Rainforest Zone (Central Africa). The Open Geology Journal 5: 56-66.

Tsozué, D., Bitom, D., Yongue-Fouateu, R., 2012. Morphology, mineralogy and geochemistry of a lateritic soil sequence developed on micaschist in the Abong-Mbang region, South-East Cameroon. South African journal of Geology 115(1): 103-116. 
Voicu, G., Bardoux, M., 2002. Geochemical behavior under tropical weathering of the Barama-Mazaruni greenstone at Omai gold mine, Guiana Shield. Applied Geochemistry 17(3): 321-336.

Voicu, G., Bardoux, M., Jébrak, M., and Voicu, D., 1996. Normative mineralogical calculations for tropical weathering profiles. Geological Association of Canade and Mineral Association of Canadian Program with Abstract, 21: A-69.

Wouatong, A.S.L., Kitagawa, R., Tchoua, M.F., Talla V., Njopwouo, D., 2005. Kaolinization of saprolite developed on pana African granite of Batié district, west province of Cameroon. Clay Science 13(1): 7-18.

Wouatong, A.S.L., Yerima, B.P.K., Yongue Fouateu, R., Mvondo Ze, A., and Ekodeck G.E., 2013. The origin of etch pits recorded on residual grain surfaces from kaolinized granitic rocks west region Cameroon. Earth Science Research 2(2): 93-110.

Yongué-Fouateu, R., 1986. Contribution à l'étude pétrologique de l'altération et des faciès de cuirassement ferrugineux des gneiss migmatitiques de la région de Yaoundé. Th. Doc. $3^{\mathrm{e}}$ cycle, Univ. de Yaoundé, 214p.

Yongue-Fouateu, R., Ghogomu, R.T., Penaye, J., Ekodeck, G.E., Stendal, H., Colin, F., 2006. Nickel and cobalt distribution in the laterites of the Lomié region, south-east Cameroon. Journal of African Earth Sciences 45(1): 33-47. 